\title{
Consumer's Preferences About Branded Verses Non Branded Mobile Phones in Faisalabad
}

\author{
Muhammad Salman Arshad", Rohail Jibran, Hafiz Ayaz ul Qasmi \\ Department of Management Sciences, Punjab Group of Colleges, University of Central Punjab, Lahore, Pakistan \\ Email address: \\ salmanarshaduaf@yahoo.com (M. S. Arshad) \\ ${ }^{*}$ Corresponding author
}

\section{To cite this article:}

Muhammad Salman Arshad, Rohail Jibran, Hafiz Ayaz ul Qasmi. Consumer's Preferences About Branded Verses Non Branded Mobile Phones in Faisalabad. Science Journal of Business and Management. Special Issue: Pure Marketing and Management. Vol. 7, No. 5, 2019, pp. 127-134. doi: 10.11648/j.sjbm.20190705.14

Received: August 31, 2019; Accepted: October 15, 2019; Published: October 23, 2019

\begin{abstract}
The present research was designed to consumer preferences about branded verses non branded mobile phones in Faisalabad. As there was a constant increase in imports of different products especially mobile phones and these imports precluded Non-Branded manufacturing industry growth. The imports were increasing to meet the demands of consumers and in return higher prices due to logistics and import duties could affect overall economy. The sample of 120 respondents will be selected haphazardly belonging to the Faisalabad for the purpose of data collection. Personal interviews and questionnaire will be used to collect the data from respondents. Suitable statistical techniques were used to analyze the gathered data. It's likely that the findings would be helpful in understanding the reasons why consumers prefer branded and non-branded mobile phones and to give the recommendations to strengthen up the strategies that could increase consumer preferences towards NonBranded mobile products over Branded mobile products. Descriptive statistics and averages were used to depict the data in SPSS 21. The results were shown in the tabular form. The likert scale was used from strongly disagree to disagree. The results showed that respondents liked branded mobile phones rather than local non-branded mobiles.
\end{abstract}

Keywords: Consumers' Preferences, Branded, Non-Branded, Mobile Phone Industry

\section{Introduction}

Because of international changes the products are rapidly changing according to customer needs. In developing countries, the customers think that the goods Branded from other countries have better grade than the Non-Branded products which creates the barrier for the Non-Branded products. Price factor customer perceives that the products obtained from western or European countries have better value of products as they do not compromise on the standards. The customer shows lower domestic products likeness and higher for Branded products that upgrades their prestige and identity. All these factors demotivate the customer to buy the NonBranded products. The contemporary research had proved that customer is mainly the key player in the market and is fickle in nature and all the activities related to marketing to businesses are dependent on the customer taste and preferences. A highest level of satisfaction to maximum customers is focused to achieve the organizational objectives and goals. Furthermore, purchase decisions depend on social, physical and economic factors that create the attraction for product. A customer trend is noticeably transposing towards superior and technologically advanced branded products. The changing behaviors of customer shows that the luxury products are now considered as essential especially in people with higher net incomes. Many multinational and domestic organizations are trying to compete in Market [1].

The main objectives of this study are as follows:

1. To investigate the consumer perception regarding domestically produced and branded mobile products.

2. To identify the factors affecting the choice of consumers between non branded produced and branded products.

3. To suggest some measures for the producer of domestic mobile products to become competitive with branded mobile products. 


\section{Literature Review}

Hardman et al., [2] paper presents a literature review of studies that investigate infrastructure needs to support the market introduction of plug-in electric vehicles (PEVs). It focuses on literature relating to consumer preferences for charging infrastructure, and how consumers interact with and use this infrastructure. This includes studies that use questionnaire surveys, interviews, modelling, GPS data from vehicles, and data from electric vehicle charging equipment. These studies indicate that the most important location for PEV charging is at home, followed by work, and then public locations. Studies have found that more effort is needed to ensure consumers have easy access to PEV charging and that charging at home, work, or public locations should not be free of cost. Research indicates that PEV charging will not impact electricity grids on the short term, however charging may need to be managed when the vehicles are deployed in greater numbers. In some areas of study the literature is not sufficiently mature to draw any conclusions from. More research is especially needed to determine how much infrastructure is needed to support the roll out of PEVs. This paper ends with policy implications and suggests avenues of future research.

Noblet et al., [3] recognized that the automobiles that were legal under law the elements that influenced the evaluation process passenger Automobiles. The conceptual framework was developed and the customer buying commitment was made under eco-labeled circumstances. The study entered first step of dual buying procedure. The socio-economic conditions were taken into account to judge the individual attribute of the customers in buying the eco-labeled automobiles. The study showed that the eco-information buying commitments better but not the excellent decision.

Dasgubta et al., [4] examined the online buying was not considered so good the customers paid little trust on the web buying process. The customer information hunt was not justified well. Due to the product image and complicated search process consumer perceptions and product presences had influenced the web buying process. The study showed that the inappropriate information, imperfect execution and display, weak information banks would not justify the authenticity of the products.

Asshidin et. al., [5] studied the imported articles and the local products in Malaysia. The local users were more attached to the imported products as they had better quality, better outlets, and durability. The methodology, convenience sampling was used. The study provided strategy for the regulatory authorizes to give substitutes and better quality to users. The study showed the significant results. The respondents were students from institutions. The data was collected by distributing the 270 questionnaires randomly. The local seller must improve the goods feature to catch the customers.

Subramanian and Yung [6] observed that the mobile industry had been developing very quickly. The study was based on life cycle assessment and based on one hundred and thirty four studies. The study included bigger range of goods. The ten types of the goods were studied. The study examined that the aim of study was to identify the impact of mobile phone industry. The results showed that quality and informational role variables played a significant role in developing consumer preferences. The data was collected from 150 respondents.

Balbanis \& Siamagaka [7] studied that the ethnocentrism had influenced on buying plan but the very less evidence had been available in real cases. The good types, affect the customer buying behavior product value, identity, manufacturing country for the dissimilarity. The data was obtained from four hundred and sixty eight respondents in USA. Ten types of the goods were discussed here in twenty two manufacturing countries. The model of logistic regression was employed for the study. The outcomes of the study showed that goods category was a primary component of the ethnocentricity. The inappropriate premises of the buying pattern in comparison of local goods with the globally recognized products.

Insch et al., [8] observed that the user of the product had agreed to purchase the local. The data was obtained from 6 cities of one country and other country. The respondents were allowed select 3 categories of the goods from any country. The results showed that the bar and toilet papers was significant. The customer paid fourteen percent more in case of muesli bar the local product. The analysis showed that the customers paid more for the local made products. The administrators were provided the comprehensive strategy to adopt their culture.

Farooq \& Ali [9] conducted the research under the name of "The national mobile brand versus international mobile brand on the consumers' buying decision". They establishes the impact of local and global mobile branding variables on consumer purchasing decisions. The aim of this study is to examine the variables that motivate and demotivate customers to buy a local or global brand or not to buy it. Maurya [10] conducted the research on "Brand preference towards mobile phone". Strong brands live in customers ' minds and are much more than just a tag for identifying and recognizing them. Brand preference is the selective call for the brand of a company instead of a product; the degree to which clients prefer one brand to another. Brand preference in the mind of clients can be achieved by establish-ing the favorable brand image. Van \& Singh [11] in their research "Brand Loyalty of Youth: Perceived Value vs. Cyber security Choices" argued on how Cyber security and security mechanisms of mobile device play an important part in product development, but are not often a top priority when customers select their favorite brand. A key factor that has been ignored as a result of the rapid pace of the market is that of youth brand loyalty. Brand loyalty remains one of the key factors in global markets that determine core consumers and security concerns feature became less important.

Aynadis [12] suggested that people are very much conscious about brand rather than the local mobile brands, therefore their tendency is large extent to the international 
mobile brands. Southworth \& Ha-Brookshire [13] researched that the branding in Asian countries, like China, has a culture and price related flexibility, therefore they can acquire customers globally and can get stronger hold in international markets. Mishra [14] argued in his paper about the relationship between brand loyalty and brand equity. The research elucidates significant relation between brand loyalty and brand equity. The sample respondents were 250 in this research.

\section{Methodology}

\subsection{Selection of Study Area}

The nature of the problem deserves the much broader coverage of the area at national level but due to obvious limitations of the student researcher (time and financial resources) the research will be restricted to city Faisalabad.

\subsection{Sample Selection and Size}

The Faisalabad city is important because it is the third largest city of Pakistan and many marketing techniques are applied by organizations and companies for selling their products and services. A representative sample of 120 respondents is selected to yield valid results. The sample was collected through Faisalabad.

\subsection{Sampling Technique}

The sample was collected through non-probability sampling technique and that was convenient sampling. It was used to collect data from respondents due to lack of availability of list because of privacy terms and conditions of electronic stores.

\subsection{Data Collection and Analysis}

A pre-tested and well-developed questionnaire is used for the purpose of collection of data through personal interviews from selected respondents. The questionnaire comprises both open ended and close ended questions. Mall intercept technique is used for data collection.

\subsection{Statistical Tools and Techniques}

The following statistical techniques were utilized for the purpose of analysis and interpretation of data. Comparative analysis will be done for comparing the domestic electronics product and imported electronic products.

\subsection{Descriptive Statistics}

To analyze the outcome of the present research, to find out the percentage and frequencies of the selected respondents, descriptive statistics is used.

\subsection{Averages}

Average is calculated by using formula:

$$
\mathrm{AM}=\sum \mathrm{X} / \mathrm{N}
$$

\subsection{Percentages}

Percentage is calculated using formula:

$$
\mathrm{P}=\mathrm{F} / \mathrm{N} \times 100
$$

Where $\mathrm{F}=$ Frequency of the class.

$\mathrm{N}=$ Total number of the observations.

\subsection{Construction of Hypotheses}

Hypothesis is defined as "A tentative explanation for an observation, phenomenon, or scientific problem that can be tested by further investigation". Hypotheses are that statement that explains or makes generalizations about a set of facts or principles, usually forming a basis for possible experiments to confirm its viability. To pursue the objectives of the research following hypothesis is constructed:

H1: Kinesthetic design has significant relationship with consumer's preference.

H2: Visual Design has significant relationship with consumer's preference.

H3: Information has significant relationship with consumer's preference.

H4: Interface quality has significant relationship with consumer's preference.

H5: Functional quality has significant relationship with consumer's preference.

\subsection{Conceptual Framework}

The following is the adopted conceptual framework in the paper.

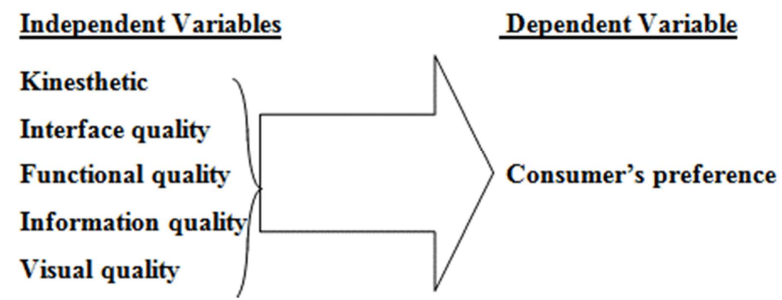

Figure 1. The adopted conceptual framework in the paper.

\section{Results}

\subsection{Age of the Respondents}

Age is very important demographic variable. It reflects the experience level of individuals. The table 1 revealed that 83.8 percent of the total respondents were less than 30 years of age, 16.3 percent were between $31-40$ years of age It showed that maximum response was from the young respondents i.e. less than 30 years of age.

Table 1. The distribution according to the Age of the respondents.

\begin{tabular}{lll}
\hline & Frequency & Percent \\
\hline $20-30$ & 65 & 65.0 \\
$31-40$ & 55 & 55.0 \\
Total & 120 & 100.0 \\
\hline
\end{tabular}

Source: Author's own calculations. 
Table 2. The distribution according to the Gender of the respondents.

\begin{tabular}{lll}
\hline & Frequency & Percent \\
\hline Male & 75 & 75.0 \\
Female & 45 & 45.0 \\
Total & 120 & 100.0 \\
\hline
\end{tabular}

Source: Author's own calculations.

Table 3. The distribution according to the marital status of the respondents.

\begin{tabular}{lll}
\hline & Frequency & Percent \\
\hline Single & 80 & 80.0 \\
Married & 40 & 40.0 \\
Total & 120 & 100.0 \\
\hline
\end{tabular}

Source: Author's own calculations.

Table 4. The distribution according to the qualification of the respondents.

\begin{tabular}{lll}
\hline & Frequency & Percent \\
\hline Matriculation & 10 & 8.3 \\
Intermediate & 15 & 12.5 \\
Bachelors & 50 & 41.7 \\
Masters & 25 & 20.8 \\
M. Phil & 20 & 20.8 \\
Total & 120 & 100.0 \\
\hline
\end{tabular}

Source: Author's own calculations.

Table 5. The distribution according to the occupation of the respondents.

\begin{tabular}{lllll}
\hline & Frequency & Percent & $\begin{array}{l}\text { Valid } \\
\text { Percent }\end{array}$ & $\begin{array}{l}\text { Cumulative } \\
\text { Percent }\end{array}$ \\
\hline Job holder & 34 & 28.3 & 28.3 & 28.3 \\
Own Business & 86 & 71.7 & 71.7 & 100.0 \\
Total & 120 & 100.0 & 100.0 & \\
\hline
\end{tabular}

Source: Author's own calculations.

Table 6. The distribution according to the income level of the respondents.

\begin{tabular}{lll}
\hline Income Level & Frequency & Percent \\
\hline $20000-30000$ & 30 & 25.0 \\
$31000-40000$ & 25 & 20.8 \\
$41000-50000$ & 45 & 37.5 \\
$51000-60000$ & 20 & 16.7 \\
Total & 120 & 100.0 \\
\hline
\end{tabular}

Source: Author's own calculations.

Table 7. Consumer choice according to Branded and Non-Branded Mobile phones.

\begin{tabular}{llll}
\hline Types of mobile phone: & Frequency & Percent & Valid Percent \\
\hline Non Branded & 50 & 41.66 & 41.66 \\
Branded & 70 & 58.34 & 58.34 \\
Total & 120 & 100.0 & 100.0 \\
\hline
\end{tabular}

Table 8. Consumer choice according to Non- branded mobile phone products.

\begin{tabular}{ll}
\hline Mobile phone categories. & Frequency \\
\hline LG & 10 \\
Samsung & 30 \\
Q-mobiles & 10 \\
Huawei & 10 \\
APPLE & 15 \\
HTC & 15 \\
OPPO & 10 \\
MI Mobiles & 10 \\
G-FIVE & 10 \\
\hline
\end{tabular}

\begin{tabular}{|c|c|c|c|c|}
\hline \multicolumn{2}{|c|}{ Mobile phone categories. } & \multicolumn{3}{|c|}{ Frequency } \\
\hline \multicolumn{2}{|c|}{ TOTAL } & \multicolumn{3}{|c|}{120} \\
\hline \multicolumn{5}{|c|}{$\begin{array}{l}\text { 4.2. Frequency Distribution of Item Scales Used in } \\
\text { Variables }\end{array}$} \\
\hline \multicolumn{5}{|l|}{ 4.2.1. Visual } \\
\hline \multicolumn{5}{|c|}{ Table 9. My phone styling looks elegant. } \\
\hline & Frequency & Percent & $\begin{array}{l}\text { Valid } \\
\text { Percent }\end{array}$ & $\begin{array}{l}\text { Cumulative } \\
\text { Percent }\end{array}$ \\
\hline $\begin{array}{l}\text { Strongly } \\
\text { disagree }\end{array}$ & 34 & 28.3 & 28.3 & 28.3 \\
\hline Disagree & 10 & 8.3 & 8.3 & 36.7 \\
\hline Neutral & 49 & 40.8 & 40.8 & 77.5 \\
\hline Agree & 4 & 3.3 & 3.3 & 80.8 \\
\hline Strongly agree & 23 & 19.2 & 19.2 & 100.0 \\
\hline Total & 120 & 100.0 & 100.0 & \\
\hline
\end{tabular}

Table 10. My phone's appearance is eye catching.

\begin{tabular}{lllll}
\hline & Frequency & Percent & $\begin{array}{l}\text { Valid } \\
\text { Percent }\end{array}$ & $\begin{array}{l}\text { Cumulative } \\
\text { Percent }\end{array}$ \\
\hline $\begin{array}{l}\text { Strongly } \\
\text { disagree }\end{array}$ & 40 & 33.3 & 33.3 & 33.3 \\
Disagree & 18 & 15.0 & 15.0 & 48.3 \\
Neutral & 12 & 10.0 & 10.0 & 58.3 \\
Agree & 41 & 34.2 & 34.2 & 92.5 \\
Strongly agree & 9 & 7.5 & 7.5 & 100.0 \\
Total & 120 & 100.0 & 100.0 & \\
\hline
\end{tabular}

Table 11. Various elements of my phone go well together.

\begin{tabular}{lllll}
\hline & Frequency & Percent & $\begin{array}{l}\text { Valid } \\
\text { Percent }\end{array}$ & $\begin{array}{l}\text { Cumulative } \\
\text { Percent }\end{array}$ \\
\hline $\begin{array}{l}\text { Strongly } \\
\text { disagree }\end{array}$ & 29 & 24.2 & 24.2 & 24.2 \\
Disagree & 13 & 10.8 & 10.8 & 35.0 \\
Neutral & 10 & 8.3 & 8.3 & 43.3 \\
Agree & 47 & 39.2 & 39.2 & 82.5 \\
Strongly agree & 21 & 17.5 & 17.5 & 100.0 \\
Total & 120 & 100.0 & 100.0 & \\
\hline
\end{tabular}

According to the above mentioned table, the respondents were asked about visual variable that various elements of their phones go well together. The results showed that $39.2 \%$ respondents were agreed with the statement. The other results are also mentioned in the table.

Table 12. My phone has proper contrast in form of right color combinations.

\begin{tabular}{|c|c|c|c|c|}
\hline & Frequency & Percent & $\begin{array}{l}\text { Valid } \\
\text { Percent }\end{array}$ & $\begin{array}{l}\text { Cumulative } \\
\text { Percent }\end{array}$ \\
\hline $\begin{array}{l}\text { Strongly } \\
\text { disagree }\end{array}$ & 33 & 27.5 & 27.5 & 27.5 \\
\hline Disagree & 11 & 9.2 & 9.2 & 36.7 \\
\hline Neutral & 52 & 43.3 & 43.3 & 80.0 \\
\hline Agree & 8 & 6.7 & 6.7 & 86.7 \\
\hline Strongly agree & 16 & 13.3 & 13.3 & 100.0 \\
\hline Total & 120 & 100.0 & 100.0 & \\
\hline
\end{tabular}

According to the above mentioned table, the respondents were asked about visual variable that while their phones has proper contrast in form of right color combinations. The results showed that $43.3 \%$ respondents were neutral with the statement. The other results are also mentioned in the table. 
Table 13. My phone matches my personality.

\begin{tabular}{lllll}
\hline & Frequency & Percent & $\begin{array}{l}\text { Valid } \\
\text { Percent }\end{array}$ & $\begin{array}{l}\text { Cumulative } \\
\text { Percent }\end{array}$ \\
\hline Strongly & 9 & 7.5 & 7.5 & 7.5 \\
disagree & & 53.3 & 53.3 & 60.8 \\
Disagree & 64 & 14.2 & 14.2 & 75.0 \\
Neutral & 17 & 10.8 & 10.8 & 85.8 \\
Agree & 13 & 14.2 & 14.2 & 100.0 \\
Strongly agree & 17 & 100.0 & 100.0 & \\
Total & 120 & & & \\
\hline
\end{tabular}

According to the above mentioned table, the respondents were asked about visual variable that while their phones matches with their personality. The results showed that $53.3 \%$ respondents disagree with the statement. The other results are also mentioned in the table.

\subsubsection{Functional}

Table 14. The phone offers a lot of latest features.

\begin{tabular}{lllll}
\hline & Frequency & Percent & $\begin{array}{l}\text { Valid } \\
\text { Percent }\end{array}$ & $\begin{array}{l}\text { Cumulative } \\
\text { Percent }\end{array}$ \\
\hline Strongly & 30 & 25.0 & 25.0 & 25.0 \\
disagree & 17 & 14.2 & 14.2 & 39.2 \\
Disagree & 16 & 13.3 & 13.3 & 52.5 \\
Neutral & 47 & 39.2 & 39.2 & 91.7 \\
Agree & 10 & 8.3 & 8.3 & 100.0 \\
Strongly agree & 120 & 100.0 & 100.0 & \\
Total & & & & \\
\hline
\end{tabular}

Table 15. My phone offers the right amount of basic features that I need.

\begin{tabular}{lllll}
\hline & Frequency & Percent & $\begin{array}{l}\text { Valid } \\
\text { Percent }\end{array}$ & $\begin{array}{l}\text { Cumulative } \\
\text { Percent }\end{array}$ \\
\hline Strongly & 27 & 22.5 & 22.5 & 22.5 \\
disagree & 28 & 23.3 & 23.3 & 45.8 \\
Disagree & 11 & 9.2 & 9.2 & 55.0 \\
Neutral & 34 & 36.7 & 36.7 & 91.7 \\
Agree & 10 & 8.3 & 8.3 & 100.0 \\
Strongly agree & 10 & 100.0 & 100.0 & \\
Total & 120 & & & \\
\hline
\end{tabular}

According to the above mentioned table, the respondents were asked about functional variable that while their phones offered the right amount of basic feature they needed. The results showed that $36.7 \%$ respondents agree with the statement. The other results are also mentioned in the table.

Table 16. My phone is loaded with more features compared to its competitors.

\begin{tabular}{|c|c|c|c|c|}
\hline & Frequency & Percent & $\begin{array}{l}\text { Valid } \\
\text { Percent }\end{array}$ & $\begin{array}{l}\text { Cumulative } \\
\text { Percent }\end{array}$ \\
\hline $\begin{array}{l}\text { Strongly } \\
\text { disagree }\end{array}$ & 26 & 21.7 & 21.7 & 21.7 \\
\hline Disagree & 28 & 23.3 & 23.3 & 45.0 \\
\hline Neutral & 46 & 38.3 & 38.3 & 83.3 \\
\hline Agree & 11 & 9.2 & 9.2 & 92.5 \\
\hline Strongly agree & 9 & 7.5 & 7.5 & 100.0 \\
\hline Total & 120 & 100.0 & 100.0 & \\
\hline
\end{tabular}

According to the above mentioned table, the respondents were asked about functional variable that while their phone offer seamless performance. The results showed that $32.5 \%$ respondents agree with the statement. The other results are also mentioned in the table.

\subsubsection{Kinesthetic}

Table 17. The shape and size of my phone makes it easy to hold in one hand with good grip.

\begin{tabular}{lllll}
\hline & Frequency & Percent & $\begin{array}{l}\text { Valid } \\
\text { Percent }\end{array}$ & $\begin{array}{l}\text { Cumulative } \\
\text { Percent }\end{array}$ \\
\hline $\begin{array}{l}\text { Strongly } \\
\text { disagree }\end{array}$ & 8 & 6.7 & 6.7 & 6.7 \\
Disagree & 7 & 5.8 & 5.8 & 12.5 \\
Neutral & 40 & 33.3 & 33.3 & 45.8 \\
Agree & 48 & 40.0 & 40.0 & 85.8 \\
Strongly agree & 17 & 14.2 & 14.2 & 100.0 \\
Total & 120 & 100.0 & 100.0 & \\
\hline
\end{tabular}

According to the above mentioned table, the respondents were asked about kinesthetic variable that while their phone shape and size of their phone is easy to hold in one hand. The results showed that $40.0 \%$ respondents agree with the statement. The other results are also mentioned in the table.

Table 18. The size of my phone makes it easy to fit and carry around in a pocket.

\begin{tabular}{lllll}
\hline & Frequency & Percent & $\begin{array}{l}\text { Valid } \\
\text { Percent }\end{array}$ & $\begin{array}{l}\text { Cumulative } \\
\text { Percent }\end{array}$ \\
\hline $\begin{array}{l}\text { Strongly } \\
\text { disagree }\end{array}$ & 17 & 14.2 & 14.2 & 14.2 \\
Disagree & 16 & 13.3 & 13.3 & 27.5 \\
Neutral & 64 & 53.3 & 53.3 & 80.8 \\
Agree & 19 & 15.8 & 15.8 & 96.7 \\
Strongly agree & 4 & 3.3 & 3.3 & 100.0 \\
Total & 120 & 100.0 & 100.0 & \\
\hline
\end{tabular}

Table 19. Phone facilitates easy working without fatigue to fingers.

\begin{tabular}{lllll}
\hline & Frequency & Percent & $\begin{array}{l}\text { Valid } \\
\text { Percent }\end{array}$ & $\begin{array}{l}\text { Cumulative } \\
\text { Percent }\end{array}$ \\
\hline $\begin{array}{l}\text { Strongly } \\
\text { disagree }\end{array}$ & 5 & 4.2 & 4.2 & 4.2 \\
Disagree & 9 & 7.5 & 7.5 & 11.7 \\
Neutral & 39 & 32.5 & 32.5 & 44.2 \\
Agree & 53 & 44.2 & 44.2 & 88.3 \\
Strongly agree & 14 & 11.7 & 11.7 & 100.0 \\
Total & 120 & 100.0 & 100.0 & \\
\hline
\end{tabular}

\subsubsection{Information}

Table 20. Information provided by phone is very clear.

\begin{tabular}{lllll}
\hline & Frequency & Percent & $\begin{array}{l}\text { Valid } \\
\text { Percent }\end{array}$ & $\begin{array}{l}\text { Cumulative } \\
\text { Percent }\end{array}$ \\
\hline $\begin{array}{l}\text { Strongly } \\
\text { disagree }\end{array}$ & 8 & 6.7 & 6.7 & 6.7 \\
Disagree & 11 & 9.2 & 9.2 & 15.8 \\
Neutral & 20 & 16.7 & 16.7 & 32.5 \\
Agree & 33 & 27.5 & 27.5 & 60.0 \\
Strongly agree & 48 & 40.0 & 40.0 & 100.0 \\
Total & 120 & 100.0 & 100.0 & \\
\hline
\end{tabular}


Table 21. The information provided by my phone is sufficient to meet my requirements.

\begin{tabular}{lllll}
\hline & Frequency & Percent & $\begin{array}{l}\text { Valid } \\
\text { Percent }\end{array}$ & $\begin{array}{l}\text { Cumulative } \\
\text { Percent }\end{array}$ \\
\hline $\begin{array}{l}\text { Strongly } \\
\text { disagree }\end{array}$ & 9 & 7.5 & 7.5 & 7.5 \\
Disagree & 11 & 9.2 & 9.2 & 16.7 \\
Neutral & 34 & 28.3 & 28.3 & 45.0 \\
Agree & 55 & 45.8 & 45.8 & 90.8 \\
Strongly agree & 11 & 9.2 & 9.2 & 100.0 \\
Total & 120 & 100.0 & 100.0 & \\
\hline
\end{tabular}

Table 22. The phone provides me error messages that help me fix problems.

\begin{tabular}{lllll}
\hline & Frequency & Percent & $\begin{array}{l}\text { Valid } \\
\text { Percent }\end{array}$ & $\begin{array}{l}\text { Cumulative } \\
\text { Percent }\end{array}$ \\
\hline $\begin{array}{l}\text { Strongly } \\
\text { disagree }\end{array}$ & 11 & 9.2 & 9.2 & 9.2 \\
Disagree & 10 & 8.3 & 8.3 & 17.5 \\
Neutral & 62 & 51.7 & 51.7 & 69.2 \\
Agree & 21 & 17.5 & 17.5 & 86.7 \\
Strongly agree & 16 & 13.3 & 13.3 & 100.0 \\
Total & 120 & 100.0 & 100.0 & \\
\hline
\end{tabular}

\subsubsection{Interface}

Table 23. The interface of the phone is smooth.

\begin{tabular}{lllll}
\hline & Frequency & Percent & $\begin{array}{l}\text { Valid } \\
\text { Percent }\end{array}$ & $\begin{array}{l}\text { Cumulative } \\
\text { Percent }\end{array}$ \\
\hline Strongly & 3 & 2.5 & 2.5 & 2.5 \\
disagree & 6 & 5.0 & 5.0 & 7.5 \\
Disagree & 29 & 24.2 & 24.2 & 31.7 \\
Neutral & 52 & 43.3 & 43.3 & 75.0 \\
Agree & 30 & 25.0 & 25.0 & 100.0 \\
Strongly agree & 120 & 100.0 & 100.0 & \\
Total & & & \\
\hline
\end{tabular}

Table 24. The interface suits my requirements.

\begin{tabular}{lllll}
\hline & Frequency & Percent & $\begin{array}{l}\text { Valid } \\
\text { Percent }\end{array}$ & $\begin{array}{l}\text { Cumulative } \\
\text { Percent }\end{array}$ \\
\hline $\begin{array}{l}\text { Strongly } \\
\text { disagree }\end{array}$ & 9 & 7.5 & 7.5 & 7.5 \\
Disagree & 10 & 8.3 & 8.3 & 15.8 \\
Neutral & 65 & 54.2 & 54.2 & 70.0 \\
Agree & 25 & 20.8 & 20.8 & 90.8 \\
Strongly agree & 11 & 9.2 & 9.2 & 100.0 \\
Total & 120 & 100.0 & 100.0 & \\
\hline
\end{tabular}

Table 25. The user interface of my phone does what I want it to do.

\begin{tabular}{lllll}
\hline & Frequency & Percent & $\begin{array}{l}\text { Valid } \\
\text { Percent }\end{array}$ & $\begin{array}{l}\text { Cumulative } \\
\text { Percent }\end{array}$ \\
\hline $\begin{array}{l}\text { Strongly } \\
\text { disagree }\end{array}$ & 8 & 6.7 & 6.7 & 6.7 \\
Disagree & 9 & 7.5 & 7.5 & 14.2 \\
Neutral & 20 & 16.7 & 16.7 & 30.8 \\
Agree & 58 & 48.3 & 48.3 & 79.2 \\
Strongly agree & 25 & 20.8 & 20.8 & 100.0 \\
Total & 120 & 100.0 & 100.0 & \\
\hline
\end{tabular}

\section{Summary}

The proposed model which related design perception to consumer based brand equity through experiential value is tested using data from not only the two samples used to develop the scale, but also from a third sample data with a mix of interactive devices, to ensure general validity of the scale as well as the model.

The socio economic characteristics of the sample respondents were analyzed by age, gender, occupation, qualification, marital status and income level.

The correlation analysis was done although with the regression analysis. The results showed that there was correlation among the variables.

The research showed that consumer prefer the branded mobile phones rather than that of non branded mobile phones.

\section{Conclusion}

For success in a competitive environment led by products with great designs, it is important that designers not only understand consumer's expectations but also are able to offer them products that thrill them with meaningful experiences and elongate the tenure of the bond that the customer shares with the brand. It is ever so pertinent for them to design more effective and desirable products for their target group.

This requires a two-fold exploration: one, how design is perceived by users and two, what is strength of its effect on experiences and consumer-brand relationships. After all, the means-end chain epitomizes this sequence by relating specific attribute perceptions to more abstract benefits, ultimately affecting consumer-brand association. More so, when it comes to design, it is critical to know if design is an amalgamation of attributes put together or islands stored in a consumer's cognition, each evaluated separately. The current work investigates and establishes the relationship amongst design, experience and brand as well as provides a way to measure consumer's perception of design, with each dimension manifested through specific attributes.

\section{Limitation and Future Direction of the Study}

A big drawback lies in the assumption of design as sole determinant of brand. Brand has been well discussed to be also determined by the marketing efforts of the same organization as well as offerings and marketing efforts of the competitors. The research must be conducted on the rural areas also. As it was a student research the sample size area must be broaden i.e in more cities of Pakistan. 


\section{Appendix}

\section{Appendices: Questionnaire}

Respected Sir/Madam

I am working on the research article name "Consumer preferences about Branded versus Non-branded Mobile phones in Faisalabad". Your precious time and valuable participation will be a great contribution towards the noble cause of knowledge creation. I ensure you that any information obtained in connection with this study will remain highly confidential.

Yours truly: Muhammad Salman Arshad

Demographics

Gender: Marital status: Qualification:

Age: Occupation: Income Level:

Religion:

Please select the branded or non-branded mobile phone listed below and give the appropriate answer.
1: Samsung
3: Nokia
2: Q-MOBILE
5: Huawei
4: $\mathrm{LG}$
7: Apple
6: Oppo
9: HTC
8: MI mobiles
10: G-FIVE

11: Any other:

Please provide the information about your selected mobile phone:

Quality features of the mobile phone:

Price:

High Low $\quad$ Moderate Satisfied Less Satisfied Dissatisfied

Quality:

Color:

Battery timing:

Storage:

The response scale is: 1. Strongly Disagree 2. Disagree 3. Neutral 4. Agree 5. Strongly Agree Scale

Visual Design (Physical appearance)

My phone styling looks elegant.

My phone's appearance is eye catching.

Various elements of my phone go well together.

4 My phone has proper contrast in form of right color combinations.

5 My phone matches my personality.

Functional Design: (working qualities)

6 The phone offers a lot of latest features.

7 My phone offers the right amount of basic features that I need.

8 My phone is loaded with more features compared to its competitors.

9 My phone offers seamless performance

10 Technical specifications of my phone allow for running two or more applications

11 I can depend on my phone's performance.

12 The quality of my phone is tough and can take a lot of abuse.

Kinesthetic design (Handling design)

13 The shape and size of my phone makes it easy to hold in one hand with good grip.

14 The size of my phone makes it easy to fit and carry around in a pocket.

15 Phone facilitates easy working without fatigue to fingers.

Interface design (Interaction qualities)

16 The interface of the phone is smooth.

17 The interface suits my requirements.

18 The user interface of my phone does what I want it to do.

19 The user interface of my phone looks very easy to navigate.

20 The user interface of my phone makes it easy to find what I need.

Information design 
21 Information provided by the phone is very clear.

22 The information provided by my phone is sufficient to meet my requirement.

23 The phone provides me an error message that helps me fix problems.

24 The instructions in my phone are concise and appropriate.

25 The information in my phone is effective in helping me complete tasks.

Consumer Preference

26 I will continuously purchase mobile phone from this mobile phone company in the future.

27 I will recommend this mobile phone company to other people.

28 I will visit this mobile company first when I want to purchase the mobile.

Q: What problem you faced in using the particular mobile phone?

Q: What do you suggest for the improvement of mobile phone industry?

"Thank you for your precious time".

\section{References}

[1] Çifci, S., Ekinci, Y., Whyatt, G., Japutra, A., Molinillo, S., \& Siala, H. (2016). A cross validation of Consumer-Based Brand Equity models: Driving customer equity in retail brands. Journal of Business Research, 69 (9), 3740-3747.

[2] Hardman, S., Jenn, A., Tal, G., Axsen, J., Beard, G., Daina, N.,... \& Plötz, P. (2018). A review of consumer preferences of and interactions with electric vehicle charging infrastructure. Transportation Research Part D: Transport and Environment, $62,508-523$.

[3] Noblet, A., \& LaMontagne, A. D. (2006). The role of workplace health promotion in addressing job stress. Health promotion international, 21 (4), 346-353.

[4] Dasgupta, G. B., Gera, S., Verma, A., \& Viswanathan, B. (2014). U.S. Patent No. 8,756,609. Washington, DC: U.S. Patent and Trademark Office.

[5] Asshidin, N. H. N., Abidin, N., \& Borhan, H. B. (2016). Perceived quality and emotional value that influence consumer's purchase intention towards American and local products. Procedia Economics and Finance, 35, 639-643.

[6] Subramanian, K., \& Yung, W. K. (2016). Review of life cycle assessment on consumer electronic products: Developments and the way ahead. Critical reviews in environmental science and technology, 46 (18), 1441-1497.

[7] Balabanis, G., Diamantopoulos, A., Mueller, R. D., \& Melewar, T. C. (2001). The impact of nationalism, patriotism and internationalism on consumer ethnocentric tendencies. Journal of international business studies, 32 (1), 157-175.
[8] Insch, A., \& Walters, T. (2017). Conceptualising the role of street art in urban tourism. CAUTHE 2017: Time for Big Ideas? Re-thinking The Field for Tomorrow, 512.

[9] Farooq, S. A., \& Ali, S. R. (2018). THE NATIONAL MOBILE BRAND VERSUS INTERNATIONAL MOBILE BRAND ON THE CONSUMERS'BUYING DECISION. Journal of Marketing, 2.

[10] Maurya, A. (2018). BRAND PREFERENCE TOWARDS MOBILE PHONE. Reflections-Journal of Management, 1 (1).

[11] Van der Westhuizen, T., \& Singh, T. (2018). Mobile Device Brand Loyalty of Youth: Perceived Value vs. Cybersecurity Choices. In Handbook of Research on Information and Cyber Security in the Fourth Industrial Revolution (pp. 531-545). IGI Global.

[12] Aynadis, Z. (2014). The 'made-in'effect: Effect of Country-oforigin on Consumers' Buying Decision of Cloths (A Case of COO's Effect on Mekelle University Students). Asian Journal of Technology \& Management Research [ISSN: 2249-0892], $4(01)$.

[13] Southworth, S. S., \& Ha-Brookshire, J. (2016). The impact of cultural authenticity on brand uniqueness and willingness to try: The case of Chinese brands and US consumers. Asia Pacific Journal of Marketing and Logistics, 28 (4), 724-742.

[14] Mishra, A. (2016). Attribute-based design perceptions and consumer-brand relationship: Role of user expertise. Journal of Business Research, 69 (12), 5983-5992. 